\title{
Indian Vegetable Diet in Immunity Development against Viral Diseases
}

\author{
A.D. Ashok*, K. Kayalvizhi and J. Ravivarman \\ Institute of Agriculture, Tamil Nadu Agricultural University, Kumulur - 621712, Trichy, India \\ *Corresponding author
}

\section{A B S T R A C T}

\begin{tabular}{|l|}
\hline Ke y w o r d s \\
Vegetarian diet, \\
Anti-viral \\
properties, \\
Immunity, \\
$\begin{array}{l}\text { Flavanols, } \\
\text { Nutraceuticals }\end{array}$ \\
\hline Article Info \\
\hline $\begin{array}{l}\text { Accepted: } \\
\text { 26 May 2020 } \\
\text { Available Online: } \\
\text { 10 June 2020 }\end{array}$ \\
\hline
\end{tabular}

Viral infections in human beings nowadays due to advent of globalization and ease of travel have underscored their prevention as a critical issue in safeguarding public health. Outbreak of many viral diseases, with the recent COVID 19, is globally lethal to human beings. The dietary management should be considered in terms of improving immunity and utilizing the anti-viral properties of few nutrients. Eating a low-fat, plantbased vegetarian diet may boost the immune system. Vegetarians have been shown in a few studies to have more effective white blood cells compared to non-vegetarians, because of a higher intake of vitamins and lower intake of fat. Hence this review tries to give out importance of Indian vegetarian diet to overcome viral infections.

\section{Introduction}

Viral infections play an important role in human diseases, and recent outbreaks in the advent of globalization and ease of travel have underscored their prevention as a critical issue in safeguarding public health. Though the medical sector reaches its golden time, many viruses lack preventive vaccines and efficient antiviral therapies, which are often beset by the generation of viral escape mutants. Due to increased global travel and rapid urbanization, epidemic outbreaks caused by emerging and re-emerging viruses represent a critical threat to public health, particularly when preventive vaccines and antiviral therapies are unavailable. Outbreak of dengue virus, influenza virus, measles virus, severe acute respiratory syndrome (SARS) virus, West Nile virus and COVID 19 (Christou, 2011, Cascio et al., 2011, Grais et al., 2011) are some of the facts we seen globally cause lethal to human beings.

\section{Viral outbreaks}

One of the greater outbreak in the recent days are Corona, which is a sole reason for death of thousands of people till date global. $\mathrm{CoV}$ is an enveloped, positive-sense single-stranded 
RNA (ssRNA) virus belonging to the Corona viridae family. The $\mathrm{CoV}$ family consists of several species and causes upper respiratory tract and gastrointestinal infections in mammals and birds. In humans, it mainly causes common cold, but complications including pneumonia and SARS can occur. (van der Hoek, 2007) The known human CoV (HCoV) includes HCoV-229E, -OC43, NL63, -HKU1, SARS-CoV (Geller et al., 2013) and the more widely known COVID'19 in 2019.

COVID'19 started as an acute viral respiratory illness in Wuhan state of china at the fag end of 2019. It spread as a pandemic to all the countries infecting lakhs of people killing many thousands globally. A lot of drugs have been tried in the setting of lifethreatening respiratory disease and still the ideal combination remains elusive. Thus, identifying novel antiviral drugs is of critical importance and natural products are an excellent source for such discoveries (Lin et al., 2014). In this deficient scientific evidence to control the pandemic, nutrition and diet should be supplemented to these patients (Adhikari et al., 2020). The dietary management should be considered in terms of improving immunity and utilizing the antiviral properties of few nutrients. Eating a lowfat, plant-based vegetarian diet may boost the immune system. Vegetarians have been shown in a few studies to have more effective white blood cells compared to nonvegetarians, because of a higher intake of vitamins and lower intake of fat (Davison, et al., 2016).

\section{Nutraceutical value of vegetables in Indian diet}

\section{Leafy vegetables}

This group includes spinach, lettuce, curly lettuce, chard, purslane, amaranthus, moringa leaves, chekurmanis, basella etc. These are important minerals (iron and calcium), vitamins (A, C, and riboflavin) and fiber sources. Young, fresh leaves contain more vitamin $\mathrm{C}$ than mature plants. The green outer leaves of lettuce and cabbage are richer in vitamins, calcium, and iron than white inner leaves. Thinner and greener leaves are more nutritious and usually have lower calories (Ulger et al., 2018). Basella have asperient, rubefacient, anticatarrhal properties, and contains antiviral substances (Lin, et al., 2009) and leaves of basella are rich in vitamin $\mathrm{A}$, vitamin $\mathrm{C}$, vitamin $\mathrm{E}$, vitamin $\mathrm{K}$, vitamin B9 (folic acid), riboflavin, niacin, thiamine and minerals such as calcium, magnesium and iron (Deb et al., 2018).

\section{Cruifers}

Broccoli and other cruciferous vegetables were proven to help boost immunity. Broccoli, cauliflower, and artichoke are frequently consumed flowering vegetables. Broccoli is a good source of iron, phosphorus, vitamins $\mathrm{A}$ and $\mathrm{C}$, and riboflavin. Cauliflower is also a good source of vitamin $C$. The nutritional value of the outer leaves of cauliflower and broccoli is much higher than the flower buds. They can be consumed raw in salads or cooked. Artichoke is a good source of minerals, especially potassium, calcium, and phosphorus, and has high dietary fiber content (Ulger et al., 2018). Vitamin C shows in vivo anti-viral immune responses at the early time of infection, especially against influenza virus, through increased production of IFN- $\alpha / \beta$ (Kim et al., 2013)

Researchers claim that sulforaphane, a chemical found in this vegetable, switches on the antioxidant genes and enzymes in specific immune cells. This effect combats free radicals in our body and prevent the disease getting worsened. Broccoli has also been found to have anti- viral properties against influenza viruses (Antonenko et al., 2013). 
Crucifers improves the effect of immune system by ensuring that immune cells in the gut and the skin known as intra-epithelial lymphocytes (IELs) function properly. Marc Veldhoen of the Babraham Institute in Cambridge, experiemted a vegetable poor diet on mice. On observation after feeding otherwise healthy mice a vegetable-poor diet for two to three weeks, 70 to 80 percent of these protective cells disappeared. Those protective IELs exist as a network beneath the barrier of epithelial cells covering inner and outer body surfaces, where they are important as a first line of defense and in wound repair. Veldhoen and their crew founds that the numbers of IELs depend on levels of a cellsurface protein called the aryl hydrocarbon receptor (AhR), which can be regulated by dietary ingredients found primarily in cruciferous vegetables (Anon, 2011).

\section{Turmeric}

Turmeric have chemical compound is known to have antioxidant, antibacterial, antiviral, cardioprotective and immune stimulating properties. Though it is a famous spices all over the world, it is used in daily diet of Indian food preparations. The bioavailability of curcumin is increased by the addition of black pepper. In a study, researchers have found that the inflammatory cytokines like the mean serum IL-1 $\beta$ and the vascular endothelial growth factor were found to be significantly reduced by curcumin therapy. This assumes significance in the wake of corona epidemic where the cytokine surge is worsening patients rather than the virus replication (Hewlings and Kalman, 2017).

\section{Carotene rich vegetables}

Liu et al., 2010, found that in a cell culture system, $\beta$-carotene could decrease the hepatosteatosis induced by the hepatitis $\mathrm{C}$ virus (HCV) by inhibiting RNA replication.
Through its activity of provitamin A and its role in the inhibition of reactive oxygen species, $\beta$-carotene has been confirmed to have a positive effect on the progression of the hepatitis virus (HBV and HCV), preventing the development of carcinoma hepatocellular (Yadav et al., 2002). Betacarotene is a powerful antioxidant that can reduce inflammation and boost immune function by increasing leucocytes in the body. Excellent sources of carotene derivatives include sweet potatoes, carrots, green leafy vegetables, pumpkin, summer squash, red and yellow bell peppers, peas, broccoli, paprika, chilli, tomato, parsley and coriander. U.S. Patent Application Publication No. 2007/0031356 and US2011/0082218 discloses UV mediated effect of beta-carotene on the expression of pro-inflammatory genes. Lin et al., 2012 described the antiinflammatory effect of beta-carotene and its potential use as anti-inflammatory agent for DNA virus infection.

I.B.R. Israeli Biotechnology Research Ltd. Patented a product (PCT No. WO 2017/029674 Al) whose compositions comprising carotenoids, particularly phytoene and phytofluene, useful in delaying viral infection in a subject and in methods of screening for anti- viral agents. German Patent Application Publication No. DE202005007462 discloses medicament or nutritional supplement composition, for combating chronic viral infections, containing vitamin $\mathrm{C}$, vitamin $\mathrm{E}$, coenzyme Q10, carotenoids, selenium, zinc and copper.

\section{Onion and garlic}

Allium sativum and Allium cepa have been recognized for their medicinal value since ancient time period. Both garlic and onion were reported to exhibit strong antiviral activity (Chen et al., 2011). Both garlic and onion have a good amount of flavonols and 
organosulfur compounds which impart medicinal property to these plants. Garlic and Onion contains flavonoids such as anthocyanins and flavanols (Slimestad et al., 2007). Isorhamnetin, Kaempferol Myricetin, and Quercetin are flavanols present in these plants (Anon, 2019). Onions (Sharma, 2019) and garlic (Amagase, 2006) contain organosulfur compounds like quercetin and allicin which are associated with inhibition of viral infection. The amount of Quercetin is more as compared to other flavanols. Quercetin and kaempferol as main flavanols. These compounds have been found to affect the growth of many viruses (Kumar and Pandey, 2013). Quercetin, a main flavanol compound in onion and garlic, have been reported to inhibit the translation and replication of RNA of many human viruses Quercetin derivatives can increase zinc uptake, which can inhibit RNA Polymerase (Sreenivasulu et al., 2010). It was proved that Polio-virus (Castrillo and Carrasco, 1987), Rhinovirus (Hellen, et al., 1989), SARS-CoV (Chen et al., 2006), Hepatitis C virus (Gonzalez et al., 2009), Ebola virus (Qiu et al., 2016), Enterovirus (Yao et al., 2018) were affected in the host cell by quercetin derivatives.

These bioactive compounds can hinder virus attachment to the host cell. They can alter transcription and translation of viral genome inside the host cell and hence also affect the viral assembly. Inhibition of viral entry into the cell and inhibition of RNA polymerase have also been postulated as mechanism of antiviral actions of this vegetable. Flavanoids present in onion and garlic have a strong inhibitory effect on virus multiplication. Phytochemicals present in these plants have been observed to block the formation of protein and genetic material in the virus (Castrillo and Carrasco, 1987, Zandi et al., 2011).

\section{Tomato}

Tomato is one of the major vegetable in Indian food diet. There are many studies recorded the nutritive and antioxidant value of tomato fruit due to its pigments, vitamins and mineral contents, we didn't come across any studies on anti viral properties of tomato fruit. But byproducts of tomato are known to have phenolic compositions in its stem, leaf, root, and whole plant. A study by Silva et al., (2014) on phenolic composition undergone in two cultivars of tomato namely Pitenza and Floradade, were analyzed by HPLC-DAD. The compounds identified were gallic acid, chlorogenic acid, ferulic acid, cafeic acid, rutin, and quercetin. In parallel, the antiviral effects of crude extracts on viral surrogates, the Escherichia virus $\mathrm{MS}_{2}$ and Escherichia phage Av-05 were evaluated. The leaf extracts from the two varieties showed the highest concentration of phenolic compounds and they represented 3174.3 and 1057.9 $\mathrm{mg} / 100 \mathrm{~g}$ dried weight of the Pitenza and Floradade cultivars, respectively. The result of MS2 and Av-05 on titeration with Pitenza and Floradade cultivar leaf extracts. shows that tomato extracts are natural sources of bioactive substances with antiviral activity.

\section{Brinjal}

Eggplants (Solanum melongena) are native to India and are one of the major vegetable used in Indian states as supplement to fish curries and dhal. Normally, in Indian folk medicinal diet, Solanum melongena and its related species are used to cure diabetes and to reduce cholesterol. Brinjal contain phytonutrients with an antioxidant role. They are important in the fight against cancer, have an antimicrobial, antiviral role, and reduce bad cholesterol. They have a nasunin anthocyan which gives the specific black color is a powerful antioxidant and an aid in the fight against free radicals that protect cell 
membranes (Butu and Rodino, 2019). A study by Di Sotto et al., (2018) reported that DR2B and DR2C extracts, obtained by ethanolic maceration of peel from commercially and physiologically ripe aubergine berries (Brinjal), were studied for the antioxidative cytoprotective properties and anti-HSV-1 activity, in line with the evidence that several antioxidants can impair viral replication by maintaining reducing conditions in host cells

\section{Elephant foot yam}

A. campanulatus (Araceae) a tuberous, stout indigenous herb commonly known as elephant foot yam, suran, grown as vegetable (Nadhkarni, 2000). A. campanulatus is basically a crop of south East Asian origin. Extracts of $A$. companulatus tuber possess protective effect against $\mathrm{H}_{2} \mathrm{O}_{2}$ induced oxidative damage. Furthermore, these tuber extracts may appeared to be beneficial in preventing $\mathrm{H}_{2} \mathrm{O}_{2}$ oxidative $\mathrm{RBC}$ damage in human and can improve $\mathrm{RBC}$ membrane permanence. (Bais and Mali, 2013)

The tubers are rich in nutrients. It is a healthy low-fat food containing a good source of protein as well as starch (Singh and Neeraj, 2012). The tuber of A. campanulatus is used for tumour, rheumatoid arthritis, carminative and liver tonic. It is also used in piles and given as the restorative in dyspepsia debility, anti-inflammatory, anti-haemorrhoidal, haemostatic, expectorant and anthelmintic (Kirtikar and Basu, 1994). A. campanulatus has been reported for its potential actions such as hepatoprotective, antioxidant, antitumor, analgesic, in-vitro cytotoxic, antibacterial, antifungal, anthelmintics, anti-inflammatory, curative effect, gastro protective, antidiarrhoeal, immunomodulatory, central nervous system activities. From plant mainly isolated quercetin, 3,5-diacetyltambulin, amblyone, salviasperanol. Moreover, total polyphenols, flavonoids and tannin contents from the present study extracts were also estimated (Bais and Mali, 2013).

On reviewing the nutraceutical and therapeutical potentials of vegetables utilized in our daily diet, we come to a conclusion that the vegan diet of Indian subcontinent is very unique and reasonable in maintain one persons physical health. The production of various vegetables for basic food diet as well as nutritious local vegetables is possible in India makes the Indian vegan diet more nutritious. Proper diet is necessary in tackling viral diseases rather than treating with drugs. Nutritional supplement is necessary to effectively counter viral illness and their ill effects. Hence a diet with a combined immune boosting and antiviral effects are important.

\section{References}

Adhikari S.P., S. Meng, Y.J. Wu, Y.P. Mao, R.X. Ye, Q. Z. Wang and H. Zhou. 2020. Epidemiology, causes, clinical manifestation and diagnosis, prevention and control of coronavirus disease (COVID-19) during the early outbreak period: a scoping review. Infectious diseases of poverty, 9: 112.

Amagase H. 2006. Clarifying the Real Bioactive Constituents of Garlic. The Journal of Nutrition, 136: 716-725.

Anonymous. 2011. Eating green veggies improves immune defenses. Science Daily, Cell Press. http//:www.sciencedaily.com/releases/2011 /10/111013121509.htm.

Anonymous. 2019. United States Department of Agriculture, National Nutrient Database for Reference.

Antonenko Y.N., L. S. Khailova, D. A. Knorre, O. V. Markova, T. I. Rokitskaya, T. M. Ilyasova, I. I. Severina, E. A. Kotova, Y. E. Karavaeva, A. S. Prikhodko, F. F. Severin, V. P. Skulachev. 2013. Penetrating Cations Enhance Uncoupling Activity of Anionic Protonophores in Mitochondria. PLoS ONE, 8: e61902-e61902. 
Bais S.S. and P.Y. Mali. 2013. Protective effect of Amorphophallus campanulatus tuber extracts against $\mathrm{H} 2 \mathrm{O} 2$ induced oxidative damage in human erythrocytes and leucocytes. Int J Green Pharm., 7:111-6.

Butu M. and S. Rodino. Fruit and VegetableBased Beverages-Nutritional Properties and Health Benefits. Natural Beverages. 2019. 13: 303-338.

Cascio A, M. Bosilkovski, A.J. RodriguezMorales and G. Pappas. 2011. The socioecology of zoonotic infections. Clin. Microbiol. Infect., 17:336-42.

Castrillo J.L. and L. Carrasco, 1987. Action of 3methylquercetin on poliovirus RNA replication. Journal of Virology, 61: 33193321.

Chen C.H, T.W Chou, L.H Cheng and C.W Ho. 2011. In vitro anti-adenoviral activity of five Allium plants. Journal of the Taiwan Institute of Chemical Engineers, 42: 228232.

Chen L., J. Li, C. Luo, H. Liu, W. Xu, G. Chen and H. Jiang. 2006. Binding interaction of quercetin-3- $\beta$-galactoside and its synthetic derivatives with SARS-CoV 3CLpro: Structure-activity relationship studies reveal salient pharmacophore features. Bioorganic and Medicinal Chemistry, 14: 8295-8306.

Christou L. 2011. The global burden of bacterial and viral zoonotic infections. Clin Microbiol Infect., 17:326-30.

Davison G., C. Kehaya and A. Jones. 2016. Nutritional and physical activity interventions to improve immunity. American journal of lifestyle medicine, 10: 152-169.

Deb P., B. V. G., Prasad, P. Munsi, and S. Chakravorty. 2018. Underutilized leafy vegetables: diversity, nutritional security and medicinal benefit in context of eastern India. In Joginder Singh, Rashmi Nigam and Wajid Hasan (eds). Advances in biodiversity conservation for sustainable development. $95-104$.

Di Sotto, A., S. Di Giacomo, D. Amatore, M. Locatelli, A. Vitalone, C. Toniolo, G.L. Rotino, R. Lo Scalzo, A.T. Palamara, M.E. Marcocci, and L. Nencioni. 2018. A Polyphenol Rich Extract from Solanum melongena L. DR2 Peel Exhibits
Antioxidant Properties and Anti-Herpes Simplex Virus Type 1 Activity In Vitro. Molecules, Basel, Switzerland. 23(8): 2066. https://doi.org/10.3390/molecules23082066

Geller C., M. Varbanov, and R.E. Duval. 2012. Human corona viruses: Insights into environmental resistance and its influence on the development of new antiseptic strategies. Viruses. 4:3044-68.

Gonzalez O., V. Fontanes, S. Raychaudhuri, R. Loo, J. Loo, V. Arumugaswami and S. W. French. 2009. The heat shock protein inhibitor Quercetin attenuates hepatitis C virus production. Hepatology, 50: 17561764.

Grais R.F., P. Strebel, P. Mala, J. Watson, R. Nandy and M. Gayer. 2011. Measles vaccination in humanitarian emergencies: A review of recent practice. Confl Health, 5:21.

Hellen C.U.T, H.G. Kraeusslich and E Wimmer. 1989. Proteolytic processing of polyproteins in the replication of RNA viruses. Biochemistry, 28: 9881-9890.

Hewlings S. and D. Kalman. 2017. Curcumin: A Review of Its' Effects on Human Health. Foods, 6: 92-92.

Kim, Y., H. Kim, S. Bae, J. Choi, S.Y. Lim, N. Lee, J.M. Kong, Y.I. Hwang, J.S. Kang and W.J. Lee. 2013. Vitamin C Is an Essential Factor on the Anti-viral Immune Responses through the Production of Interferon- $\alpha / \beta$ at the Initial Stage of Influenza A Virus (H3N2) Infection. Immune network, 13(2), $70-74$. https://doi.org/10.4110/in.2013.13.2.70.

Kirtikar K.R. and B.D. Basu. Indian Medicinal Plants, Dehradun Publisher Ltd., India: Ed. 2, 4: 2609- 10.

Kumar S. and A. K. Pandey. 2013. Chemistry and Biological Activities of Flavonoids: An Overview: 1-16.

Lin H.W., T.J. Chang, D.J. Yang, Y.C. Chen, M. Wang, Y.Y. Chang. 2012. Regulation of virus-induced inflammatory response by $\beta$ carotene in RAW264.7 cells. Food Chem 134:2169-2175

Lin L.J., Y.Y. Hsiao, and C.G. Kuo, 2009. Discovering indigenous treasures: promising indigenous vegetables from 
around the world. AVRDC- The World vegetable center publication No.09-720. AVRDC- The world vegetable center, Shanhua, Taiwan. 317.

Lin L.T., W.C. Hsu and C.C. Lin. 2014. Antiviral natural products and herbal medicines. J Tradit Complement Med. 4(1):24- 35. doi:10.4103/2225-4110.124335

Liu Q., S. Bengmark and S. Qu. 2010. Nutrigenomics therapy of hepatisis $\mathrm{C}$ virus induced-hepatosteatosis.

$\mathrm{BMC}$

Gastroenterol. 10: 49.

Nadkarni K.M. 2000. Indian Materia Medica, Popular Prakashan, Mumbai. Ed.3, 1: 94-5.

Qiu X., A. Kroeker, S. He, R. Kozak, J. Audet, M. Mbikay and M. Chrétien. 2016. Prophylactic Efficacy of Quercetin 3- $\beta$ - O d-Glucoside against Ebola Virus Infection. Antimicrobial Agents and Chemotherapy, 60: 5182-5188.

Sharma N. 2019. Efficacy of Garlic and Onion against virus. International Journal of Research in Pharmaceutical Sciences, 10: 3578-3586.

Silva N., S. Ruiz-Cruz, C. Chaidez-Quiroz, J. Ornelas-Paz, M. Lopez, E. Marquez Rios and M. Estrada. 2014. Chemical constitution and effect of extracts of tomato plants byproducts on the enteric viral surrogates. International journal of environmental health research. 25. 1-13. 10.1080/09603123.2014.938030.

Singh A. and W. Neeraj. 2012. Osmotic dehydration of Amorphophallus paeoniifolius slices and it's phyto- chemical investigation. Int J. Pharm
Life Sci., 3(1): 1797- 801.

Slimestad R. , T. Fossen, I. M. Vagen. 2007. Onions: A Source of Unique Dietary Flavonoids. Journal of Agricultural and Food Chemistry, 55: 10067-10080.

Sreenivasulu K., P. Raghu and K. M. Nair. 2010. Polyphenol-Rich Beverages Enhance Zinc Uptake and Metallothionein Expression in Caco-2 Cells. Journal of Food Science, 75: 123-128.

Ulger T. G., A. N. Songur, O. C. and F. P. Cakiroglu. 2018. Role of Vegetables in Human Nutrition and Disease Prevention, Vegetables - Importance of Quality Vegetables to Human Health. Ed. Asaduzzaman and Toshiki Asao. In. Intech Open, DOI: 10.5772/intechopen.77038.

Van der Hoek L. 2007. Human coronaviruses: What do they cause? Antivir Ther. 12:6518.

Yadav, D., H.I. Hertan, P. Schweitzer, E.P. Norkus, C.S. Pitchumoni. 2002. Serum and liver micronutrient antioxidants and serum oxidative stress in patients with chronic hepatitis C. Am. J. Gastroenterol. 97: 26342639.

Yao C., C. Xi, K. Hu, W. Gao, X. Cai, J. Qin and Y. Wei. 2018. Inhibition of enterovirus 71 replication and viral 3C protease by quercetin. Virology Journal, 15: 116-116.

Zandi K., B.T. Teoh, S.S Sam, P.F Wong, M. Mustafa and S. Abubakar. 2011. Antiviral activity of four types of bioflavonoid against dengue virus type-2. Virology Journal, 8.

\section{How to cite this article:}

Ashok, A.D., K. Kayalvizhi and Ravivarman, J. 2020. Indian Vegetable Diet in Immunity Development against Viral Diseases. Int.J.Curr.Microbiol.App.Sci. 9(06): 3411-3417. doi: https://doi.org/10.20546/ijcmas.2020.906.404 